\title{
Prospek Relasi Dewan Perwakilan Daerah Dengan Partai Politik
}

\author{
Bagir Manan, Indra Perwira, dan Mei Susanto \\ Fakultas Hukum Universitas Padjadjaran Bandung Jawa Barat Indonesia \\ Jln. Imam Bonjol No. 21 Bandung, 40132 Jawa Barat Indonesia \\ bagir.manan@fh.unpad.ac.id; indra@unpad.ac.id; dan m.susanto@unpad.ac.id
}

Received: 20 Desember 2020; Accepted: 7 April 2021; Published: 2 Juni 2021

DOI: 10.20885/iustum.vol28.iss2.art1

\begin{abstract}
This article analyzes the relationship between the Regional Representative Council (DPD) and political parties that are often confronted diametrically. The questions presented, what is the historical factor for the formation of the DPD and the comparison of the practices of several countries in relation to regional representative bodies and political parties? What are the prospects for the relationship between the DPD and political parties in the future? This article aims to provide a different perspective on the relationship between the DPD and political parties from the historical, comparative and conception point of regional representation bodies. Through the socio-legal method, it was concluded that, first, historically the formation of the DPD was designed to be filled by individuals, not political parties. However, the practice of some countries shows that regional representative bodies generally cannot be separated from political parties. The lesson is that separating the DPD and political parties "strictly" can be said to always be violated because it is not in accordance with the natural conditions of filling the DPD directly by the people, who are influenced by the strength of the network and political parties. Second, whether or not there are political party affiliations in the DPD will not have a significant impact due to the limited authority of the DPD, so what is needed is the granting of significant DPD authority in the legislative process and supervision through the bicameral model. Thus, the prospect of the relationship between the DPD and political parties in the future can contribute to each other according to the DPD's already significant authority while still providing space for individuals.
\end{abstract}

Key Words:Bi-cameral, political parties, regional representative council, regional elements

Abstrak

Artikel ini menganalisis relasi Dewan Perwakilan Daerah (DPD) dan partai politik yang kerap dihadapkan secara diametral. Pertanyaan yang diajukan, bagaimana faktor historis pembentukan DPD dan perbandingan praktik beberapa negara dalam kaitan antara badan perwakilan kedaerahan dengan partai politik? Dan bagaimana prospek hubungan DPD dengan partai politik di masa akan datang? Artikel ini bertujuan memberikan perspektif berbeda terhadap relasi DPD dan partai politik dari sudut sejarah, perbandingan, dan konsepsi badan perwakilan kedaerahan. Melalui metode socio-legal, disimpulkan, pertama, secara historis pembentukan DPD memang didesain untuk diisi oleh perorangan, bukan partai politik. Namun, praktik beberapa negara menunjukkan badan perwakilan kedaerahan secara alamiah umumnya tidak dapat dilepaskan dari partai politik. Pelajarannya, memisahkan DPD dan partai politik secara "ketat" dapat dikatakan akan selalu dilanggar karena tidak sesuai dengan kondisi alamiah pengisian DPD secara langsung oleh rakyat, yang dipengaruhi kekuatan jaringan dan partai politik. Kedua, ada tidaknya afiliasi partai politik di DPD tidak akan memberikan dampak signifikan karena keterbatasan kewenangan DPD, sehingga yang diperlukan adalah pemberian kewenangan DPD yang signifikan dalam proses legislasi dan pengawasan melalui model bikameral. Dengan demikian, prospek hubungan DPD dan partai politik di masa akan datang dapat saling berkontribusi sesuai kewenangan DPD yang sudah signifikan dengan tetap memberi ruang bagi perseorangan.

Kata-kata Kunci: Dewan Perwakilan Daerah; partai politik; bikameral; perwakilan kedaerahan 


\section{Pendahuluan}

Hubungan antara Dewan Perwakilan Daerah (DPD) dan partai politik menimbulkan berbagai persoalan ketatanegaraan di Indonesia sebagai akibat dari praktik beberapa anggota DPD yang menjadi anggota partai politik. Padahal ketentuan UUD 1945 Pasal 22E ayat (4) mengatur peserta pemilihan umum untuk memilih anggota DPD adalah perorangan, yang membedakannya dengan Pasal 22E ayat (3), peserta pemilihan umum untuk memilih anggota Dewan Perwakilan Rakyat (DPR) adalah partai politik. Hal ini menunjukkan adanya pengkhususan bagi DPD yang bukan berasal dari partai politik. Namun dalam tataran praktik, tidak sedikit anggota DPD yang berasal dari partai politik, sehingga menunjukkan "asumsi" adanya pelanggaran terhadap ketentuan UUD 1945. Praktik semacam ini mengemuka saat pemilihan Ketua DPD pada pertengahan tahun $2017^{1}$ karena sebelumnya yang bersangkutan telah menjadi ketua umum salah satu partai politik. ${ }^{2}$ Praktik serupa diikuti oleh beberapa anggota DPD lainnya yang juga menjadi anggota partai politik bahkan pengurus partai politik. ${ }^{3}$

Fenomena anggota partai politik menjadi anggota DPD sebenarnya telah berlangsung lama. Sebut saja Pimpinan DPD pertama (2004-2009) pernah aktif sebagai anggota partai politik, ${ }^{4}$ ataupun ada Wakil Ketua Majelis Permusyawaratan Rakyat (MPR) 2009-2014 unsur DPD yang sebelumnya adalah anggota partai politik. ${ }^{5}$ Namun 'afiliasi kepentingan' dengan partai politik pada saat menjadi anggota dan unsur pimpinan DPD (dan MPR sebagai unsur DPD) memang sulit diketahui. Fenomena keterkaitan DPD dan partai politik naik cukup tajam pada periode 2014-2019, sekitar 78 orang anggota DPD berafiliasi

\footnotetext{
1 “Oesman Sapta Terpilih Menjadi Ketua DPD Gantikan Mohammad Saleh", https:// news.detik.com/berita/d-3464194/oesman-sapta-terpilih-menjadi-ketua-dpd-gantikan-mohammadsaleh, diakses 20 April 2020.

2 "Oesman Sapta Odang Terpilih Jadi Ketua DPD", https://nasional.kompas.com/read/2017/ 04/04/02314801/oesman.sapta.odang.terpilih.jadi.ketua.dpd, diakses 20April 2020,

3 "Dianggap Galau, Anggota DPD Ramai-Ramai Ke Parpol”, diakses 20 April 2020, https://www.tribunnews.com/nasional/2017/02/04/dianggap-galau-anggota-dpd-ramai-ramai-ke-parpol, diakses 20 April 2020.

4 "Pimpinan DPD Ginandjar Kartasamita", https://dpd.go.id/pimpinan-dpd/ginandjar-kartasasmita-, diakses 29 Maret 2021. Ginandjar Kartasasminta merupakan Ketua DPD Periode 2004-2009, sebelumnya aktif di Partai Golkar dan menjadi Wakil Ketua MPR Periode 1999-2004 dari Fraksi Partai Golkar.

5 "Taufiq Kiemas Pimpin MPR", https://koran.tempo.co/read/nasional/178000/taufiq-kiemas-pimpinmpr, diakses 29 Maret 2021. Dalam berita tersebut Pimpinan MPR 2009-2014 adalah Taufiq Kiemas (PDI-P), Hajrianto Y. Thohari (Golkar), Lukman Hakim Saepuddin (PPP), Melani Leimina Suharli (Demokrat), dan Ahmad Farhan Hamid (DPD). Disebutkan Ahmad Farhan Hamid sebelumnya pernah menjabat Ketua Fraksi PAN DPR 1999-2004.
} 
dengan partai politik, ${ }^{6}$ bahkan 8 orang anggota DPD diantaranya menjadi pengurus inti partai politik. ${ }^{7}$

Praktik anggota DPD yang menjadi anggota partai politik tersebut menemui 'benturan' saat Komisi Pemilihan Umum (KPU) mengeluarkan Peraturan KPU No. 26 Tahun 2018 tentang Perubahan Kedua Atas Peraturan KPU Nomor 14 Tahun 2018 tentang Pencalonan Perseorangan Peserta Pemilihan Umum Anggota Dewan Perwakilan Daerah. KPU mencoret Calon Anggota DPD yang menjadi pengurus partai politik pada kontestasi Pemihan Umum Tahun 2019. KPU mendasarkannya pada Putusan Mahkamah Konstitusi (MK) No. 30/PUU-XVI/2018 yang menentukan bahwa pemilihan umum anggota DPD adalah perseorangan, sehingga calon anggota DPD tidak boleh menjadi pengurus partai politik. Putusan MK No. 30/PUUXVI/2018 masih memberikan kesempatan bagi calon anggota DPD yang terdaftar sebagai pengurus partai politik untuk mengundurkan diri dari kepengurusan, sehingga pencalonan sebagai anggota DPD tidak menjadi gugur. Namun, sebagian tidak menerima begitu saja, sehingga mengajukan pengujian Peraturan KPU tersebut ke Mahkamah Agung (MA), dan melalui Putusan No. 65 P/HUN/2018, MA berpendapat bahwa Putusan MK No. 30/PUU-XVI/2018 tidak berlaku surut bagi peserta pemilihan umum anggota DPD tahun 2019 yang telah mengikuti berbagai rangkaian proses. Persoalannya, KPU bersikukuh pada peraturannya untuk mencoret calon anggota DPD yang terdaftar sebagai pengurus partai politik dan tidak mau mengundurkan diri.

Berangkat dari persoalan relasi DPD dengan partai politik tersebut di atas, artikel ini hendak menganalisis hubungan DPD dengan partai politik secara konseptual dalam konteks ketatanegaraan Indonesia, dan tidak untuk mengomentari Putusan MK No. 30/PUU-XVI/2018 maupun Putusan MA No. 65 P/HUN/2018. 8 Analisis dilakukan dengan melihat sisi historis pembentukan

\footnotetext{
6 "Jumlah Afiliasi Anggota DPD Dalam Partai Politik," Indonesian Parliamentary Center, http://ipc.or.id/wp-content/uploads/2017/04/garis.jpg, diakses 20 April 2020.

7 Sutan Sorik, "Pengurus Parpol Dilarang Jadi Anggota DPD: Kepentingan Politik Praktis atau Amanah Konstitusi?," Pusat Penelitian Politik LIPI, http://www.politik.lipi.go.id/kolom/kolom-2/politik-nasional/1249pengurus-parpol-dilarang-jadi-anggota-dpd-kepentingan-politik-praktis-atau-amanah-konstitusi\#ftn5, diakses 20 April 2020.

${ }^{8}$ Salah satu yang membahas soal Putusan MK dan Putusan MA tersebut dapat dilihat dalam tulisan Pan Mohamad Faiz dan Muhammad Reza Winata, "Respons Konstitusional Larangan Calon Anggota Dewan Perwakilan Daerah sebagai Pengurus Partai Politik," Jurnal Konstitusi, Vol. 16, No. 3, 2019, hlm. 532-558.
} 
DPD dan praktik beberapa negara, serta konsepsi-konsepsi yang ada dalam konteks badan perwakilan yang bersifat kedaerahan/teritorial. Melalui tinjauan historis dan perbandingan, diharapkan dapat memberikan perspektif yang berbeda terhadap relasi DPD dan partai politik tersebut, serta memberikan analisis kemungkinan-kemungkinan prospek hubungan DPD dengan partai politik di masa yang akan datang. ${ }^{9}$

\section{Rumusan Masalah}

Berdasarkan latar belakang yang telah disampaikan di atas, rumusan masalah yang diajukan dalam artikel ini, pertama, bagaimana faktor historis pembentukan DPD dan perbandingan praktik beberapa negara dalam kaitan antara badan perwakilan yang bersifat kedaerahan dengan partai politik? Kedua, bagaimana prospek hubungan DPD dengan partai politik di masa yang akan datang?

\section{Tujuan Penelitian}

Berdasarkan rumusan masalah di atas, maka tujuan penulisan artikel ini adalah, pertama, menganalisis dan mengetahui faktor historis pembentukan DPD dan perbandingan praktik beberapa negara untuk kemudian dianalisis dalam kaitan antara badan perwakilan yang bersifat kedaerahan dengan partai politik. Kedua, membuat desain prospek hubungan DPD dengan partai politik di masa yang akan datang.

\section{Metode Penelitian}

Artikel ini menggunakan metode penelitian socio-legal research dengan titik tekan pada study of law in context dan research policy.10 Adapun yang dimaksud dengan socio-legal research disini adalah mencoba mengkaji hubungan pengaruh antara kaidah hukum dengan kenyataan di masyarakat ${ }^{11}$, yakni dalam penerapan kebijakan pemisahan DPD dan partai politik dalam praktik ketetanegaraan

9 Misalnya Suryawan dan Setiabudhi yang mengatakan DPD tidak dapat merangkap jabatan sekaligus menjadi anggota partai politik berdasarkan pendekatan normatif semata. Lihat Putu Wawan Suryawan dan I Ketut Rai Setiabudhi, "Sah Tidaknya Anggota Dewan Perwakilan Daerah Masuk Partai Politik", Kertha Negara, Vol. 6, No. 3, 2018, hlm. 1-15.

${ }^{10}$ Baca Reza Banakar, Normativity in Legal Sociology: Methodological Reflection in Late Modernity, Normativity in Legal Sociology, Springer, Cham, 2015, hlm. 48-49.

11 Bagir Manan, "Penelitian Terapan Di Bidang Hukum", Makalah pada Lokakarya Peranan Naskah Akademik Dalam Penyusunan Peraturan Perundang-Undangan, BPHN, Jakarta, 9-11 Desember 1993, hlm. 18. 
Indonesia (research policy) dan bagaimana konteks tidak dapat dilepaskannya badan perwakilan dari pengaruh partai politik (study of law in context). Patut dicatat, metode socio-legal tidak menanggalkan studi doktrinal, melainkan senantiasa mengupas dan menuntaskan terlebih dahulu soal kerangka normatif suatu masalah, untuk kemudian dianalisis lebih mendalam terhadap berbagai persoalan yang muncul secara kontekstual.12 Berdasarkan hal tersebut, maka relasi DPD dan partai politik dilihat terlebih dahulu dalam kerangka normatif dengan menggunakan pendekatan sejarah pengaturan, untuk kemudian mencoba memperbandingkan dengan praktik beberapa negara berkenaan relasi badan perwakilan yang bersifat kedaerahan dengan partai politik. Selanjutnya relasi DPD dan partai politik dikontekstualisasi dalam praktik bernegara di Indonesia, serta kewenangan DPD yang terbatas sehingga memerlukan cara pandang yang lebih tepat berkaitan dengan prospek relasi DPD dan partai politik. Data dikumpulkan berdasarkan pengalaman keterlibatan penulis pertama dalam Perubahan UUD 1945 dan pengamatan terhadap praktik DPD dan partai politik yang mencuat dan terangkum dalam pemberitaan media-media nasional, untuk kemudian dilakukan analisis secara kualitatif preskriptif guna menilai dan menemukan rekomendasi yang tepat terhadap prospek relasi antara DPD dan partai politik di masa yang akan datang.

\section{Hasil Penelitian dan Pembahasan}

\section{Historikal Pembentukan DPD dan Perbandingan Praktik Beberapa Negara}

Sejarah pembentukan DPD tidak dapat dilepaskan dari konsepsi MPR berdasarkan UUD 1945 (asli) dan suasana sosio-politik saat reformasi. MPR berdasarkan UUD 1945 (asli) yang disusun dalam sidang Badan Penyelidik Usaha Persiapan Kemerdekaan (BPUPK), digagas beranggotakan anggota DPR, utusan daerah dan utusan golongan. ${ }^{13}$ Patut dicatat, meskipun ada unsur "utusan daerah", tetapi "the Framers of the Constitution" tidak pernah mengarahkan MPR terdiri dari dua kamar (bikameral). Dengan demikian, utusan daerah tidak terpisah dari

\footnotetext{
12 Sulistyowati Irianto, "Memperkenalkan Kajian Sosio-Legal dan Implikasi Metodologisnya", dalam Adrian Bedner, dkk. (ed), Kajian Sosio-Legal, Pustaka Larasan, Bali, 2012, hlm. 3.

13 Saafroedin Bahar, A.B. Kusuma, dan Nannie Hudawati, ed., Risalah Sidang Badan Penyelidik Usaha-Usaha Persiapan Kemerdekaan Indonesia (BPUPKI), Panitia Persiapan Kemerdekaan Indonesia (PPKI), Sekretariat Negara RI, Jakarta, 1995, hlm. 181.
} 
anggota MPR yang berasal dari anggota DPR dan utusan golongan. Kedudukan, tugas, wewenang, tanggungjawab, hak dan kewajiban anggota MPR yang berasal dari DPR, utusan daerah dan utusan golongan, tidak ada perbedaan satu sama lain. Walau demikian, menurut para "the Framers of the Constitution", keanggotaan MPR utusan daerah, bukan saja untuk menjamin representasi daerah, tetapi untuk menjamin pula kepentingan-kepentingan daerah agar dapat senantiasa menjadi bagian tak terpisahkan dari kepentingan yang bersifat nasional. ${ }^{14}$

Dalam praktik sebelum Reformasi 1998, cara pengisian keanggotaan MPR (termasuk utusan daerah) menunjukkan gejala yang tidak demokratis. Misalnya saat Orde Lama, tidak pernah ada pemilihan umum untuk mengisi badan perwakilan, baik pusat maupun daerah (DPR, MPR, DPRD Provinsi/Kabupaten/Kota), semua jabatan itu diisi melalui pengangkatan oleh Presiden. ${ }^{15}$ Sementara di masa Orde Baru, ada pemilihan umum secara teratur setiap lima tahun. Tetapi, praktik ketatanegaraan menciptakan utusan daerah baik secara politik maupun fungsional tidak mandiri. Utusan daerah justru terkoopotasi oleh Sekretariat Bersama (Sekber) Golkar yang lebih menampakkan tangan politik monolitik, bukan sebagai the real democratic instrument yang mewujudkan kedaulatan rakyat (meskipun ada dua partai lain). Hal serupa terjadi pada utusan golongan. Praktik tidak demokratis tersebut secara umum sebagai dampak UUD 1945 tidak dijalankan sebagaimana mestinya ataupun UUD 1945 memberi peluang, baik karena kekosongan atau ketidakjelasan. Para penggagas dan pendukung reformasi 1998 oleh karenanya berpandangan bahwa salah satu sumber tidak berjalannya staatsidee atau staatsfundamentalnorm yang menjadi kandungan UUD 1945 adalah UUD 1945 itu sendiri. Karena itu, untuk lebih menjamin pelaksanaan staatsidee atau staatsfundamentalnorm, seperti demokrasi, negara hukum, konstitusionalisme, perlu perubahan UUD 1945. Ketentuan-ketentuan tentang MPR termasuk yang harus diubah, karena MPR yang secara konstitusional pemegang kedaulatan

\footnotetext{
${ }^{14}$ Lihat Pidato Soepomo 15 Juli 1945, dalam Ibid., hlm. 269.

15 Penetapan Presiden Nomor 2 Tahun 1959 Tentang Majelis Permusyawaratan Rakyat Sementara. Lihat Juga Peraturan Presiden Nomor 12 Tahun 1959 tentang Susunan Majelis Permusyawaratan Rakyat Sementara., Anggota MPRS tediri dari 94 orang utusan daerah, 200 orang utusan golongan (13 macam golongan: golongan tani, buruh/pegawai negeri, golongan pengusaha nasional, koperasi, angkatan bersenjata, veteran, alim ulamaIslam, Katolik, Protestan, Hindu Bali-, pemuda, wanita, wartawan, dan cendikiawan/pendidikan. Lihat juga Penetapan Presiden Nomor 4 Tahun 1960 tentang Dewan Perwakilan Rakyat Gotong Royong., Anggota DPRGR terdiri atas golongan politik 130 orang, golongan karya 152 orang, dan satu orang wakil Irian Barat.
} 
rakyat, dalam kenyataan merupakan "the dummy" pemegang kekuasaan monolitik belaka.

Salah satu obyek perubahan MPR adalah mengenai utusan daerah. Utusan daerah mesti dijadikan suatu lembaga yang mandiri yaitu DPD disamping DPR. Pada saat itu terbetik gagasan membentuk sistem perwakilan dua kamar (bikameral). ${ }^{16}$ MPR sebagai badan perwakilan tertinggi terdiri dari dua kamar yaitu DPR dan DPD. Namun hasil perubahan, DPD menjadi badan perwakilan tersendiri disamping MPR dan DPR.17 Sebagai badan yang mewakili daerah (sebagai pengganti utusan daerah), menurut para penggagasnya bukan merupakan perwakilan politik. Sebagai konsekuensi, para anggota DPD harus duduk sebagai perorangan, tidak melalui atau berafiliasi dengan partai politik. Inilah yang mungkin sering disebut sebagai original intent pembentukan DPD yang sering kali jadi rujukan. Dari original intent ini, tepatkah untuk kemudian memisahkan DPD dengan partai politik secara 'ketat' dalam arti terpisah sama sekali?

Sebelum lebih dalam membahas persoalan tersebut, berikut dilakukan penelahaan terhadap perbandingan praktik beberapa negara berkenaan dengan relasi badan perwakilan 'kedaerahan' dengan partai politik. Mungkin ada yang berpendapat, ulasan perbandingan di bawah ini kurang begitu tepat. Unsur badan perwakilan yang dicatat adalah unsur sistem perwakilan dua kamar (bicameral), sedangkan DPD (Indonesia) bukan unsur sistem perwakilan dua kamar. Pandangan itu tidak salah. Namun yang akan menjadi obyek ulasan di bawah ini bertolak dari satu persamaan yaitu sebagai "utusan daerah" baik yang bernama negara bagian, provinsi dalam federasi, atau provinsi di negara kesatuan. Unsur perwakilan yang bukan perwakilan daerah tidak akan menjadi obyek ulasan. Inti ulasan di bawah ini adalah "menemukan hubungan badan perwakilan utusan daerah dengan partai politik" sesuai dengan tema artikel ini.

16 Tim Penyusun Naskah Komprehensif, Naskah Komprehensif Perubahan Undang-Undang Dasr Negara Republik Indonesia Tabun 1945: Latar Belakang, Proses, dan Hasil Pembahasan 1999-2002, Buku III, Sekretariat Jenderal dan Kepaniteraan Mahkamah Konstitusi, Jakarta, 2010, hlm. 1085-1086.

17 Rumusan UUD 1945 sama sekali tidak mencerminkan konsep perwakilan dua kamar, karena MPR mempunyai anggota dan lingkungan kewenangan sendiri, seperti DPR dan DPD. Bagir Manan, DPR, DPD dan MPR dalam UUD 1945 Baru, FH UII Press, Yogyakarta, 2003, hlm. 5. 


\section{a. Senat Amerika Serikat}

Semula anggota Senat Amerika Serikat dipilih oleh badan legislatif masingmasing negara bagian (Konstitusi Amerika 1787, Pasal I, Section 3 angka 1) "The Senate of the United States..., chosen by the legislature there of, for six years, ..." Berdasarkan Amendemen ke-XVII (1913), anggota Senat Amerika Serikat dipilih langsung oleh rakyat masing-masing negara bagian "The Senate of the United States ..., elected by the people thereof, ...". Bagaimana hubungan Senator (demikian pula anggota DPR (House of Representative) dengan partai? Kita lazim membaca atau mendengar sebutan "Senator Demokrat" atau "Senator Republik". Demikian pula sebutan "anggota DPR Demokrat" atau "anggota DPR Republik".18 Dengan demikian, Senat yang merupakan representasi negara bagian (kedaerahan) memiliki relasi dengan partai politik. Namun perlu dicatat hubungan itu tidak menunjukkan hubungan yang erat (ketat). Peran individual Senator Amerika Serikat (demikian pula peran individual anggota DPR) lebih mengedepan daripada peran partai politik. Meskipun pencalonan mereka dikaitkan dengan partai, tetapi peran individual lebih menentukan untuk terpilih atau tidak terpilih.

Model pencalonan anggota Senat AS seperti diungkapkan di atas terjadi karena partai politik Amerika Serikat tergolong pada "the weak party system"19 dan tidak ada sistem disiplin partai yang ketat seperti di Australia atau negara-negara Eropa pada umumnya. Oleh karena itu, lazim mendengar atau membaca, dalam satu isu ada anggota Senat Demokrat yang mendukung atau menolak suatu usul atau RUU, demikian pula anggota yang berasal dari Republik, yang berbeda dengan garis kebijakan partainya. Hal serupa terjadi pula pada DPR. Setiap anggota Senat atau anggota DPR pada dasarnya independen dari partainya. Eric M. Uslaner dan Thomas Zittal dalam Comparative Legislative Behaviour mengatakan:

"Members are independent entrepreneurs who serve on legislative committees that have independent of party pressure and often at odds with party goals. Members run for reelection with no fear that the national party can deny them renomination or even cost them another term". ${ }^{20}$ (Anggota Kongres adalah anggota independen yang

\footnotetext{
18 James Q. Wilson, John J. Dilulio Jr., dan Meena Bose, American Government: Institutions \& Policies, Cengage Learning, Stamford, 2015, hlm. 314-315.

${ }^{19}$ Ibid., 320.

${ }^{20}$ Eric M. Uslaner dan Thomas Zittal, "Comparative Legislative Behaviour", in The Oxford Handbook of Political Institution, ed. R. A. W. Rhodes, Sarah A. Binder, dan Bert A. Rockman, Oxford University Press, New York, 2006, hlm. 457.
} 
bebas berkegiatan dalam komisi-komisi legislatif dan bebas dari tekanan partai, bahkan acapkali berselisih dengan tujuan-tujuan partai. Para anggota yang maju mencalonkan untuk dipilih kembali tidak khawatir (tidak takut), partai akan menolak pencalonan mereka, atau meskipun membebani mereka untuk masa jabatan selanjutnya).

Walaupun hubungan antara Senator dan partai politik sangat longgar (begitu pula anggota DPR), tetapi proses pencalonan mereka tetap bertalian dengan partai politik dan mereka senantiasa dikenal sebagai orang partai. Contoh Senat Amerika ini menunjukkan sisi hubungan badan perwakilan 'kedaerahan' yang erat dengan partai politik khususnya dalam pencalonan. Selain itu perlu dicatat pula, bahwa keberadaan partai politik, tidak membuat Senat (maupun DPR) Amerika sepenuhnya diisi partai politik, melainkan juga terdapat anggota independen. ${ }^{21}$

\section{b. Senat Australia}

Australia merupakan negara federal yang parlemennya terdiri dari dua kamar yakni Senat dan DPR (House of Representatives).22 Pasal 7 Konstitusi Australia menentukan anggota Senat Australia dipilih langsung oleh masingmasing penduduk negara bagian. Setiap negara bagian merupakan satu daerah pemilihan dan setiap negara bagian diwakili oleh enam orang Senator dengan masa jabatan enam tahun. Secara konstitusional, anggota Senat mewakili negara bagian. Bagaimana kenyataannya dan relasinya dengan partai politik? Untuk memperoleh gambaran, ada dua sumber yang dapat diberikan:

Pertama, Hakim Barwick pada Kasus Provinsi Victoria vs. Commonwealth 1975, di dalam putusannya mengatakan:

"It is evident from the terms of the Constitution that the Senate was intended to represent the States... As distinct from House of Representatives which represent the electors the throughout Australia. It is often said that the Senate has, in this respect, failed of the purpose. This may be so due partly to the party system and the nature of electoral system...."23 (Memang benar, berdasarkan ketentuan konstitusi, Senat dimaksudkan mewakili negara bagian, yang membedakannya dengan DPR

${ }^{21}$ Data Congressional Research Service Maret 2020 menunjukkan Senat Amerika terdiri dari 53 Republicans, 45 Democrats dan 2 Independents, sementara DPR Amerika tediri dari 236 Democrats, 198 Republicans, 1 Independent. Lihat Jennifer E. Manning, Membership of the 116 th Congress: A Profile, Congressional Research Service, 2020, https://www.senate.gov/reference/ resources/pdf/R41647.pdf.

22 Australian Government Solicitor, Australia's Constitution With Overview and Notes by the Ausralian Government Solicitor, Barton, 2010, hlm. iv-v.

${ }^{23}$ Gabriel Moens, John Trone, dan R.D. Lumb, The Constitution of the Commonwealth of Australia Annotated, 9th Editio, LexisNexis Butterworths, Chatswood DC, 2016, hlm. 45. 
yang mewakili pemilih untuk seluruh Australia. Namun, acapkali dikatakan, dalam kaitan ini Senat tidak berhasil (gagal) mewujudkan tujuan ini. Hal ini disebabkan, sebagian karena pengaruh kehadiran partai dan sebagian lain akibat sistem pemilihan).

Kedua, S.R. Sharma sebagai editor Encyclopedia of Constitutional Law mengatakan:

"When the constitution was adopted it was hoped and expected that Senate would serve as the agency within the structure of the national government that would protect the rights of the states. But this has not been realized..., Senators, as well as Representatives, are elected as members of the national political parties and the success of their individual campaigns for election defend largely on the support accorded them by the parties. It would be very difficult task for the prospective Senator, facing the difficulties of a state - wide candidacy and campaign, to win out alone against opponent who had the support of the political party machine. Only loyal party man has any real chance of the winning Senate elections". ${ }^{4}$ (Pada saat konstitusi ditetapkan, diharapkan dan diangan-angankan Senat sebagai wakil dalam susunan pemerintahan nasional, akan melindungi hak-hak negara bagian. Tetapi hal ini belum (pernah) terwujud ... Para senator sebagaimana juga para anggota DPR dipilih sebagai anggota partai yang bersifat nasional dan keberhasilan mereka dalam kampanye perorangan agar terpilih sebagian besar tergantung pada dukungan yang diperoleh dari partai. Merupakan tugas yang sulit bagi calon Senator menghadapi pencalonan secara sendirian menghadapi lawan yang memperoleh bantuan mesin partai. Hanya orang partai yang loyal yang akan benar-benar memiliki peluang memenangkan pemilihan Senat).

Senat Australia yang hendak diposisikan mewakili negara bagian secara penuh tidak dapat terlepas dari partai politik, khususnya sebagai dampak sistem pemilihan yang membuat dukungan partai politik menjadi salah satu kunci meraih kursi. Hal ini dapat dilihat dari hasil pemilihan Senat Australia dimana anggota independen (tanpa partai) merupakan minoritas anggota Senat. ${ }^{25}$ Contoh Australia ini cukup menarik, mengingat walaupun partai politik dapat masuk ke dalam Senat, namun keberadaan anggota independen tetap ada, sehingga dalam hal tertentu dimungkinkan memberikan warna dalam penentuan kebijakan di Senat.

\section{c. Bundesrat Jerman}

Parlemen Jerman adalah badan perwakilan dua kamar yang terdiri dari Bundestag dan Bundesrat. Bundestag adalah badan perwakilan untuk seluruh

${ }^{24}$ S.R. Sharma, ed., Encyclopaedia of Constitutional Law No. 5, Anmol Publications Pvt Ltd, New Delhi, 2003, hlm. 85 .

${ }^{25}$ Bede Harris, A New Constitution for Australia, Cavendish Publishing Limited, London, 2002, hlm. 221. 
rakyat yang diisi dengan pemilihan langsung oleh rakyat (Pasal 38 Basic Law Federal Republic of Germany). Sementara Bundesrat adalah wakil negara bagian (Lander). Pasal 51 Basic Law Federal Republic of Germany menyatakan anggota Bundesrat diangkat pemerintah negara bagian, dan masing-masing negara bagian mempunyai wakil paling sedikit tiga orang dan paling banyak lima orang anggota.

Sejauh mana Bundesrat yang mewakili negara bagian ada kaitan dengan partai politik? Herman Finer dalam The Major Governments of Modern Europe menuliskan:26

"Its members are appointed by the Governments of the Lander. Therefore, those who wish to rule Government at the level of the federal authority have a keen interest in the political party composition of the Land Governments. None of the Lander has a Government based on a single majority party, all of them have coalition. The interest of each political party in the Bund is to raise the power of the afficialate in each Land to the maximum strength, either to succeed in ruling with the Bundesrat's help or to block the Government by obstruction in Bundesrat. (Anggota-anggota (maksudnya anggota Bundesrat) diangkat oleh pemerintah negara bagian. Karena itu, siapapun yang berkeinginan memerintah Jerman pada tingkat pemerintahan federal, mempunyai kepentingan yang dalam terhadap susunan partai politik pada pemerintahan negara bagian. Tidak ada pemerintahan negara bagian yang hanya didasarkan pada mayoritas tunggal suatu partai, semua pemerintahan negara bagian berbentuk koalisi. Kepentingan setiap partai politik dalam lingkungan federasi (Bund) adalah memiliki kekuasaan maksimum, agar sukses dalam memerintah dengan sokongan Bundesrat atau untuk menghalang-halangi pemerintah dengan melakukan hambatan-hambatan di Bundesrat).

Dalam buku yang sama, didapati pula keterangan bahwa "The political party most and do intervene heavily in the election campaign in the Lander and in the formation of their cabinets and the formulation of their policies in the Bundesrat"27 (partai politik sangat banyak dan kuat melakukan intervensi dalam kampanye pemilihan di negara bagian dan dalam pembentukan kabinet dan penyusunan kebijakan di Bundesrat). Soal pengaruh partai politik di Bundesrat juga dikatakan Horst Risse:

"The Basic Law makes it possible for the political parties to take part in the political decision-making process. ...., it can be said that the parties are the real "policymakers". Therefore, the decisions of the Bundesrat may be influenced by party political considerations. In a "party democracy" with its close-knit relations between the federal and state levels of government it would be illusory to try to differentiate between "objective policy" and "party policy". Political decision-making takes place on the basis of parliamentary majorities and the governments formed on this basis at

\footnotetext{
${ }^{26}$ Herman Finer, The Major Governments of Modern Europe, Methuen, London, 1960, hlm. 498.

${ }^{27}$ Ibid., hlm. 499.
} 
the Lander level. They are represented by leading politicians from the Lander exerting political influence at the federal level through the Bundesrat"28 (UUD Jerman memungkinkan partai politik mengambil bagian dalam proses pengambilan keputusan politik. ..., dapat dikatakan bahwa partai-partai adalah "pembuat kebijakan yang nyata". Karena itu, keputusan Bundesrat dapat dipengaruhi oleh pertimbangan politik partai. Dalam "pesta demokrasi" dengan hubungan erat antara pemerintah federal dan negara bagian yang disebut "Lander", adalah suatu ilusi untuk mencoba membedakan antara "kebijakan obyektif" dan "kebijakan partai". Pengambilan keputusan politik dilakukan atas dasar mayoritas parlemen dan pemerintah yang dibentuk atas dasar pemahaman tersebut di tingkat Lander. Mereka diwakili oleh politisi terkemuka dari Lander yang memberikan pengaruh politik di tingkat federal melalui Bundesrat).

Mencermati perbandingan praktik beberapa negara di atas, badan perwakilan yang mewakili daerah, dalam kenyataannya menempatkan keterkaitan atau tidak dapat dipisahkan dari partai politik. Bahkan ada yang sama sekali tergantung pada partai politik. Konstruksi ini menunjukkan bahwa melepaskan begitu saja sebuah badan perwakilan dengan partai politik akan sangat sulit, mengingat secara alamiah proses pengisian anggota badan perwakilan 'kedaerahan' di dalam negara yang demokratis, baik langsung maupun tidak langsung akan selalu membutuhkan sokongan dari partai politik. Selain itu, perlu dicatat pula, bahwa keberadaan partai politik pada badan perwakilan kedaerahan, tidak selalu mutlak, melainkan dapat dikombinasikan dengan anggota independen. Ini sesuai dengan prinsip demokrasi, kesetaraan, bahwa siapapun dan dari kelompok manapun dapat saja bersaing untuk mengisi badan perwakilan, dengan syarat mengikuti prosedur yang telah ditetapkan. Dari bekal perbandingan ini pula, pernyataan yang memisahkan DPD dengan partai politik secara tegas dalam ketatanegaraan Indonesia layak untuk dikaji ulang. Dalam artian, perlu ada renovasi dan inovasi terhadap model badan perwakilan di Indonesia, lebih khusus DPD sehingga akan dapat memberikan kontribusi lebih signifikan dalam demokrasi dan ketatanegaraan Indonesia.

\section{Prospek Hubungan DPD dengan Partai Politik}

Setelah mencermati praktik beberapa negara berkenaan dengan badan perwakilan kedaerahan/negara bagian sebagaimana telah diulas dapat dikatakan sulit untuk memisahkan keikutsertaan partai politik dengan badan perwakilan

\footnotetext{
${ }^{28}$ Horst Risse, "The Bundesrat in the Legislative Process of Federal Republic of Germany," in Second Chambers: Bicameralism Today, ed. R.C. Tripathi, Rajya Sabha Secretariat, New Delhi, 2002, hlm. 110.
} 
kedaerahan. Kalau demikian, dalam konteks Indonesia mengapa dipersoalkan ketika sejumlah anggota DPD menjadi anggota bahkan pengurus partai politik? Sesuatu yang sulit bahkan tidak mungkin dielakkan. Ada beberapa alasan mempersoalkan masuknya partai politik ke dalam DPD. Pertama, dasar historis konseptual. Secara historis-konseptual, DPD tidak dapat dipisahkan dari unsur utusan daerah di MPR. Bahkan, kehadiran DPD merupakan upaya memperkokoh secara konstitusional utusan daerah sebagaimana telah disinggung. Di dalam konsepsi para Founding Father's yang sekaligus Framers of the Constitution, utusan daerah bukan unsur perwakilan kekuatan politik melainkan kepentingan daerah. Unsur dan sebagai penyalur kekuatan politik adalah partai politik yang diwakili anggota-anggota DPR. Dasar konseptual yang sama didapati pada negara lain seperti Senat Australia dan Amerika Serikat.

Di Australia, peran partai politik berkembang sejalan dengan sistem pemerintahan parlementer yang bertumpu pada dukungan politik, khususnya partai politik di parlemen. Sementara Senat Amerika Serikat merupakan salah satu "the great compromise" untuk menjamin keseimbangan perwakilan antara negara-negara bagian, dan untuk itu ada wakil yang mewakili negara bagian di samping wakil rakyat. Di dalam perkembangannya walaupun peran individual anggota Senat tetap lebih mengedepan, tetapi mekanisme melalui partai politik tetap diperlukan. Dalam konteks Indonesia, DPD yang dibentuk dengan motivasi yang sama sebagai perwakilan daerah dengan melepaskannya dari partai politik, pada kenyataannya mengalami proses serupa seperti di Amerika dan Australia.

Kedua, penipisan kepercayaan terhadap partai politik dan orang-orang partai politik. Penipisan kepercayaan tersebut dapat terjadi karena beberapa persepsi:

(1)Partai politik yang menjalar sejak reformasi (memanfaatkan jaminan dan perlindungan atas kebebasan, cq kebebasan berpendapat dan berkumpul) kebanyakan didirikan tanpa landasan konseptual tertentu sebagai dasar dan platform yang akan diperjuangan dan dilaksanakan apabila berhasil duduk atau turut serta dalam penyelenggaraan negara.

(2)Akibat ketiadaan landasan konseptual, partai lebih nampak sebagai alat memperoleh atau duduk dalam kekuasaan. Memang harus diterima, partai 
politik adalah sarana memperjuangkan kekuasaan. Tetapi bukan sekedar kekuasaan demi kekuasaan (power for the sake of power), melainkan kekuasaan untuk merealisasikan konsep-konsep penyelenggaraan negara baik atas landasan idiil tertentu atau cita-cita seperti cita-cita sosial-ekonomi tertentu sesuai dengan tatanan konstitusi yang berlaku.

(3)Partai-partai politik lebih mencerminkan gerakan elitisme yang tertutup demi kepentingan aktivis partai belaka. Bahkan di sana-sini terkesan (sadar atau tidak sadar) dihinggapi unsur feodalisme dan oligarkisme yang bersifat hirarkis dan "koncoisme" atau bahkan dinasti keluarga.

(4)Penipisan kepercayaan terhadap partai politik dipertebal pula karena sejumlah orang-orang partai yang duduk dalam pemerintahan dan lembaga-lembaga negara di pidana atau dalam proses pemidanaan karena korupsi. Penipisan juga dipengaruhi oleh faktor orang yang ada di partai politik yang suka berpindahpindah partai. Tidak perlu khawatir, disebut "pagi dele sore tempe" alias "menclamencle" tidak konsisten terhadap garis perjuangannya. Soal pindah memindah ini, bagi orang atau kelompok orang tertentu mungkin dianggap bersifat persoonlijk, sehingga akan tetap setia mendukungnya. Namun adapula yang tidak peduli "don't care" atas fenomena tersebut, karena bagi rakyat sama saja.

Bagaimana persoalan penipisan kepercayaan terhadap partai politik ini juga berpengaruh terhadap DPD? Praktik hadirnya anggota DPD yang merupakan anggota bahkan pimpinan partai politik memberikan dampak pada penipisan kepercayaan kepada DPD itu sendiri. DPD yang diharapkan mampu menghadirkan pengimbangan kepentingan daerah terhadap kepentingan politik, justru menambah bobot kepentingan politik.

Apakah makna kehadiran partai politik di DPD diukur dengan kedudukan dan peran DPD dalam tatanan penyelenggaraan negara? Sesuai dengan yang telah disinggung, pada saat perubahan UUD 1945 kemungkinan mengubah sistem perwakilan menjadi sistem bikameral. Pertanyaannya, mengapa gagasan itu tidak terwujud walaupun telah dibentuk DPD? Tidaklah jelas argumen yang dipergunakan para anggota MPR yang akhirnya menyepakati konstruksi yang ada sekarang ini. DPD merupakan lembaga negara tersendiri terpisah dari DPR dan MPR. Anggota DPD -seperti anggota DPR- adalah anggota MPR. 
Ada beberapa kemungkinan tidak terwujudnya gagasan sistem bikameral, pertama, mungkin ada yang mempertalikan sistem bikameral dengan federalisme seperti Konstitusi RIS (ada DPR disamping Senat). Semangat federalisme bukanlah staatsidee UUD 1945 (negara kesatuan), bahkan pengalaman Republik Indonesia Serikat yang berbentuk federal menunjukkan perpecahan bangsa dan negara. Kedua, apabila DPD menjadi unsur bikameralisme bersama DPR berarti mengubah MPR menjadi badan legislatif yang terdiri dari DPR dan DPD. Sedangkan menurut staatsidee -sebagaimana digagas para "Framers of the Constitution"- MPR bukanlah badan legislatif. Ada juga ahli yang menggolongkan MPR sebagai badan legislatif dengan membedakan: “DPR adalah badan legislatif sehari-hari (membentuk undang-undang), sementara MPR adalah badan legislatif yang tidak sehari-hari. Tetapi 'ajaran' ini, tidak sesuai dengan pemikiran dasar para penyusun UUD 1945. Ketiga, Perubahan UUD 1945 justru lebih menegaskan “DPR memegang kekuasaan membentuk undang-undang" [Pasal 20 ayat (1)]. Kalau ketentuan ini dianalogikan dengan UUD Amerika Serikat Pasal 1 Sec. 1 angka (1) yang menyatakan "all legislative power herein granted shall be vested in a Congress", memperlihatkan ada maksud "DPR adalah satu-satunya pemegang kekuasaan legislatif". Sayangnya ketentuan Pasal 20 ayat (1) dikendorkan sendiri dalam UUD 1945 yang menyatakan "Presiden berhak mengajukan usul inisiatif" dan “ikut serta membahas RUU untuk mendapat persetujuan bersama".

Berdasarkan catatan di atas, DPD sebagai wakil daerah seolah-olah tidak dimaksudkan sebagai unsur badan legislatif. Keikutsertaan DPD untuk mengajukan usul kepada DPR dalam proses pembentukan undang-undang sama sekali tidak menunjukkan DPD sebagai unsur kekuasaan legislatif. Rumusan Pasal 22D ayat (1) UUD 1945 hanya menentukan DPD "dapat mengajukan kepada DPR" RUU yang berkaitan dengan otonomi daerah, hubungan pusat dan daerah, pembentukan dan pemekaran serta penggabungan daerah, pengelolaan sumber daya alam dan sumber daya ekonomi lainnya, serta yang berkaitan dengan perimbangan keuangan pusat dan daerah. Frasa "dapat mengajukan kepada DPR" tidak imperatif karena hanya bersifat opsional ditambah klausul "diajukannya" kepada DPR, sehingga DPR dapat saja menolak pengajuan RUU dari DPD 
tersebut. Disinilah DPD tidak memiliki hak inisiatif, tidak turut serta memberikan dan menyetujui atau tidak menyetujui RUU, termasuk tidak memiliki hak amandemen terhadap RUU. Hal-hal yang merupakan esensi kekuasaan legislatif dimanapun di dunia ini.

Hal tersebut selain dapat dilihat pada ayat (1), dapat juga dilihat pada Pasal 22D ayat (2) UUD 1945 menyatakan: (i) DPD ikut membahas RUU yang berkaitan dengan otonomi, hubungan pusat-daerah, pembentukan / pemekaran / penggabungan daerah, pengelolaan sumber daya alam, sumber daya ekonomi dan lain-lain, perimbangan keuangan pusat-daerah; (ii) DPD memberikan pertimbangan kepada DPR terhadap RUU APBN, RUU yang berkaitan dengan pajak, pendidikan dan agama. Terhadap klausul "ikut membahas" sama sekali tidak menunjukkan DPD menjadi kekuasaan legislatif, karena ikut membahas belum menunjukkan kekuasaan atau fungsi legislatif. Demikian halnya dengan kekuasaan memberi pertimbangan (advisory). DPD akan tergolong sebagai kekuasaan legislatif apabila disertai sekurang-kurangnya hak menyetujui atau tidak menyetujui. Walaupun diakui, ada negara-negara yang menjalankan sistem bikameral dengan membatasi kekuasaan badan perwakilan seperti House of Lords (Inggris), atau Bundesrat (Jerman), yang tidak disertai hak inisiatif dan hak amendemen, namun memiliki hak untuk memberikan persetujuan atau penolakan terhadap sebuah rancangan undang-undang. Memang ada Putusan MK No. 92/PUU-X/2012 yang meluruskan UU MPR, DPR, DPD, dan DPRD (MD3) karena tidak melibatkan DPD dalam pembahasan RUU tertentu, namun Putusan MK tersebut belum cukup memberikan posisi signifikan DPD dalam legislasi karena hanya sebagai pembahas bukan pengambil keputusan/pemberi persetujuan. ${ }^{29}$

Selain dalam bidang legislasi, lemahnya kewenangan sebagai tanda DPD bukan badan legislatif yang sebenarnya, juga dapat dilihat dalam Pasal 22D ayat (3) UUD 1945: (i) DPD "dapat melakukan pengawasan" atas pelaksanaan undangundang mengenai: otonomi daerah, pembentukan, pemekaran dan penggabungan daerah, hubungan pusat dan daerah, pengelolaan sumber daya alam dan sumber daya ekonomi lainnya, pelaksanaan anggaran pendapatan dan

${ }^{29}$ Lihat juga ulasan Enny Nurbaningsih, "Implikasi Putusan Mahkamah Konstitusi Nomor 92/PUUX/2012 dan Alternatif Model Hubungan Kelembagaan Terkait Pembentukan Undang-Undang”, Mimbar Hukum, Vol. 27, No. 1, 2015, hlm. 1-13. 
belanja negara, pajak, pendidikan, dan agama; untuk selanjutnya (ii) hasil pengawasan disampaikan kepada DPR sebagai bahan pertimbangan untuk ditindaklanjuti. Lagi-lagi fungsi pengawasan DPD tidak bersifat mengikat, hanya kaidah persuasif belaka, bahkan hasil pengawasan tidak dapat ditindaklanjuti sendiri, melainkan harus disampaikan kepada DPR. Itupun hanya sebagai bahan pertimbangan DPR. Hal ini menunjukkan bahwa DPD hanya badan pelengkap DPR, bahkan badan yang membantu DPR dalam menjalankan tugas dan wewenangnya. Peran ini kemudian dinilai tidak jauh berbeda dengan keberadaan tenaga ahli yang juga membantu memberikan masukan bagi DPR.

Munculnya upaya penambahan kewenangan pengawasan DPD dalam UU No. 2 Tahun 2018 tentang Perubahan Kedua UU No. 17 Tahun 2014 tentang MPR, DPR, DPD dan DPRD, berupa pemantauan dan evaluasi atas rancangan peraturan daerah dan peraturan daerah, adalah sesuatu yang tidak dikenal dalam sistem konstitusi dan praktik ketatanegaraan di dunia. Pemerintah daerah dalam sistem negara kesatuan itu berada dalam lingkungan jabatan eksekutif (pemerintah), karenanya pengawasannya (termasuk peraturan daerah) adalah kewenangan kekuasaan eksekutif. Penambahan kewenangan DPD tersebut mengada-ada dan tidak sesuai dengan konsep manapun.

Adapun persoalan penempatan DPD yang lemah tersebut, karena adanya kesalahan persepsi mengenai badan perwakilan daerah. Badan perwakilan daerah dipandang diadakan hanya semata-mata untuk mewakili dan ikut mengelola kepentingan daerah. Hal yang membuat kewenangan badan perwakilan daerah seperti DPD diberikan kewenangan yang terbatas bahkan tidak mengikat. Padahal, secara konseptual gagasan perwakilan daerah sebagai unsur legislatif dimaksudkan sebagai cara mengikutsertakan daerah dalam menentukan politik dan pengelolaan negara melalui pembentukan undang-undang dan pengawasan atas jalannya pemerintahan, bukan sekedar persoalan-persoalan daerah. ${ }^{30} \mathrm{Meg}$ Russel menyatakan, representing the territories and their interests at the national level, providing a forum for the different territorial units to debate policies and agree common

\footnotetext{
${ }^{30}$ Manan, DPR, DPD dan MPR, Op.Cit., hlm. 63. Lihat juga Firman Manan, "Dewan Perwakilan Daerah Republik Indonesia Dalam Sistem Pemerintahan Republik Indonesia”, Jurnal Ilmu Pemerintahan, Vol. 1, No. 1, 2015, hlm. 48-61.
} 
positions, linking the national parliament to territorial assemblies or governments. ${ }^{31}$ Kamar kedua dalam badan perwakilan, mewakili wilayah dan kepentingannya di tingkat nasional, menyediakan forum bagi unit-unit teritorial yang berbeda untuk dapat memperdebatkan kebijakan dan menyetujui hal yang dapat disepakati, serta dalam rangka menghubungkan parlemen nasional dengan badan perwakilan di daerah atau pemerintahan di daerah.

Bagaimana dengan gagasan dan wacana agar menegaskan kekuasaan legislatif DPD? Kalau gagasan ini terwujud, ada beberapa konsekuensi konstitutional. Pertama, menegaskan atau memberikan kekuasaan legislatif kepada DPD berarti ada dua lembaga negara yang menjalankan kekuasaan legislatif yakni DPR dan DPD. Dengan demikian, ada pembagian kekuasaan legislatif (sharing of legislative power). Hal semacam ini hanya dapat dilakukan dalam sistem perwakilan dua kamar (bicameral). Konsekuensinya (seperti diuraikan di atas) bukan sekedar perubahan ketentuan dalam UUD, tetapi bertalian dengan 'staatsidee' sistem perwakilan menurut UUD 1945. Kalau jalan ini ditempuh, bukanlah sesuatu yang salah, karena kehidupan berkonstitusi (bernegara) yang sehat adalah kemestian mengikuti perkembangan baik perkembangan konseptual maupun kebutuhan untuk lebih melapangkan pelaksanaan sendi-sendi bernegara dan mencapai citacita bangsa. Barangkali patut dipertimbangan ungkapan umum yang menyatakan "Konstitusi itu dibuat untuk kita, bukan kita untuk konstitusi".

Kedua, apabila DPD dan DPR sama-sama sebagai unsur kekuasaan legislatif, badan apakah yang akan menaungi keduanya sebagai satu kesatuan badan legislatif? Seperti Parlemen di Inggris yang menaungi House of Lords dan House of Commons, Staten General Belanda yang menaungi Eerste Kamer dan Tweede Kamer, Congress Amerika Serikat yang menaungi House of Representatives dan Senate, atau Parlemen India yang menaungi Lok Sabha dan Raja Sabha. Seandainya menjadi perwakilan bikameral (DPR dan DPD), apakah keduanya berada di bawah naungan MPR? Dengan demikian MPR berubah status menjadi badan legislatif. Unsur MPR terdiri dari lembaga DPR dan DPD bukan terdiri dari anggota DPR dan anggota DPD. Perlu pula dicatat, perubahan status MPR menjadi badan

${ }^{31}$ Meg Russell, "The Territorial Role of Second Chambers", The Journal of Legislatives Studies, Vol. 7, No. 1, 2001, hlm. 109-110. 
legislatif tidak berarti akan mengubah atau meniadakan kekuasaan MPR yang ada sekarang. Kekuasaan-kekuasaan itu tetap melekat pada MPR sebagai badan legislatif yang menaungi DPR dan DPD.

Bagaimana relasi DPD dan partai politik? Apakah ada perbedaan kehadiran partai politik di DPD sebagai unsur kekuasaan legislatif atau bukan unsur kekuasaan legislatif?

Kehadiran partai politik di lingkungan DPD yang tidak menjalankan kekuasaan legislatif seperti sekarang, tidak akan banyak berpengaruh pada keseluruhan fungsi legislatif (baik dalam pembentukan undang-undang maupun di luar pembentukan undang-undang). Ia hanya melekat pada kepentingan individual anggota DPD yaitu ada basis konstituen sebagai pendukung. Dalam beberapa kejadian, DPD bahkan terlihat sebagai tempat perpindahan anggota partai politik, baik karena sudah tidak lagi berkeinginan berkompetisi di DPR, naik kelas dari anggota DPRD menjadi anggota DPD, ataupun dalam rangka berbagi jabatan kenegaraan yang dapat diisi oleh partai politik. Walaupun anggota DPD banyak diisi oleh partai politik sebagaimana telah disinggung pada pendahuluan, namun kehadirannya tidak memberikan dampak signifikan sebagai akibat terbatasnya kewenangan DPD. Bahkan, soal relasi DPD dan partai politik saat ini, walau KPU telah berpegang pada Putusan MK No. 30/PUUXVI/2018 yang membuat calon-calon anggota DPD harus membuat pernyataan mundur dari partai politik, hasil pemilihan umum 2019 menunjukkan bahwa banyak anggota DPD yang sebelumnya adalah anggota partai politik. Sebagaimana telah diulas di pendahuluan, tidak jelas apakah yang bersangkutan masih menjalankan misi partai politik tertentu atau tidak. ${ }^{32}$

Peran kehadiran partai politik di DPD akan berbeda kalau DPD menjalankan kekuasaan legislatif. Berbagai policy (kebijakan) legislatif DPD dapat dipengaruhi oleh dasar politik partai. Hal itu akan terjadi apabila berkembang sistem disiplin partai dan partai memiliki platform perjuangan yang jelas. Tetapi dapat juga terjadi, peran individual anggota DPD tetap kuat seperti para Senator Amerika Serikat karena tidak ada disiplin partai (the weak party system), lebih-lebih -seperti sekarang-

32 Dapat dilihat dari website DPD yang menunjukkan riwayat hidup anggota DPD yang sebagiannya adalah pernah aktif di partai politik. “Anggota DPD," diakses 20 April 2020, https://dpd.go.id/Fanggota/Anggota/34. 
partai-partai politik tidak memiliki platform perjuangan yang jelas kecuali sekedar mendudukkan anggota di lembaga-lembaga penyelenggara negara.

Di dalam praktik-pun, muncul koalisi anggota DPR dan anggota DPD yang berasal dari satu provinsi (atau dua provinsi), seperti Forum Bersama (Forbes) Aceh, ${ }^{33}$ dan Forum Papua (Forum Aspirasi dan Komunikasi Masyarakat) Papua dan Papua Barat ${ }^{34}$. Bersatunya anggota DPR dan anggota DPD dari satu provinsi (atau dua provinsi) tersebut dalam rangka memperjuangkan aspirasi kedaerahan. Praktik ini menunjukkan bahwa peranan anggota DPD sebagai wakil daerah tidak mampu secara kuat untuk memperjuangkan aspirasi kedaerahan. Selain faktor kewenangan yang terbatas, hal tersebut disebabkan sedikitnya jumlah anggota DPD setiap provinsi yang hanya berjumlah 4 orang sebagai akibat pembatasan jumlah anggota DPD tidak lebih dari sepertiga jumlah anggota DPR menurut Pasal 22C ayat (2) UUD 1945. Padahal, secara konsepsional, jumlah anggota DPD yang sama setiap provinsi, adalah dalam rangka menyeimbangkan aspirasi antara satu daerah yang besar penduduknya dengan yang sedikit penduduknya. ${ }^{35}$ Namun, ketiadaan kewenangan DPD yang memadai, membuat upaya menyeimbangkan aspirasi tersebut menjadi tidak bermakna.

Praktik tersebut menunjukkan bahwa aspirasi kedaerahan tidak selalu berasal dari anggota DPD. Anggota DPR yang notabene adalah anggota partai politik juga merupakan pembawa aspirasi kedaerahan. Hal ini setidaknya dapat dilihat dari anggota-anggota DPR khususnya dari daerah dengan otonomi khusus seperti Aceh, Papua, dan Papua Barat. Anggota DPR tersebut tidak hanya mewakili partai, tapi juga mewakili kepentingan kedaerahan. Di dalam praktik tersebut, semakin tipis garis kepentingan partai politik pada saat berbicara aspirasi kedaerahan. Bahkan dalam beberapa hal, karena faktor budaya masyarakat di daerah tertentu seperti Aceh dan Papua, keberadaan wakil rakyat di tingkat nasional, lebih mengedepankan aspek kedaerahan dibandingkan aspek politik.

33 "Anggota Forbes Haru dan Apresiasi Pemerintah Aceh", http://humas.acehprov.go.id/anggotaforbes-haru-dan-apresiasi-pemerintah-aceh/, diakses 20 Desember 2020.

34 "Ketua MPR Inisiasi Forum Aspirasi Papua-Papua Barat", https://news.detik.com/berita/d4806671/ketua-mpr-inisiasi-forum-aspirasi-papua-papua-barat, diakses 20 Desember 2020.

35 Bandingkan dengan Senat Amerika, the framers of the constitution Amerika, menentukan anggota Senat dua orang setiap negara bagian adalah dalam rangka menyeimbangkan negara bagian yang besar dengan negara bagian yang kecil. Richard A. Baker, "The Senate of the United States", in Second Chambers, ed. R.C. Tripathi, Rajya Sabha Secretariat, New Delhi, 2002, hlm 256. 
Gagasan DPD sebagai badan legislasi yang sebenarnya (dengan kewenangan yang memadai) dan memiliki relasi dengan partai politik, juga memungkinkan simbiosis mutualisme. Kehadiran DPD sebagai kamar kedua dalam badan perwakilan, sebagaimana praktik beberapa negara, adalah dalam rangka memberdayakan pengalaman dan kebijaksanaan kamar kedua. Misalnya saja keanggotaan House of Lords di Inggris yang merupakan Majelis Tinggi, tidak hanya berisikan perwakilan bangsawan maupun agama, melainkan mengangkat mantan anggota House of Commons yang senior dan berpengalaman, misalnya saja para mantan Perdana Menteri. ${ }^{36}$ Demikian juga di Senat Amerika yang secara umum anggota Senat adalah politisi senior yang berpengalaman, bahkan sebagian besar pernah menjadi anggota DPR Amerika. ${ }^{37}$ Hal ini sejalan dengan konsepsi Senat, yang diambil dari pengalaman Romawi Kuno bahwa istilah Senat dimaksudkan untuk "council of old men" dewan orang tua dan berakar dari Bahasa Latin Senex yang berarti 'senior'.38

Di dalam konteks inilah fungsi DPD dapat berperan untuk memperkuat dan menyempurnakan perwakilan "representation" serta reflection "kebijaksanaan" terhadap keberadaan DPR dan juga pemerintahan. ${ }^{39}$ Belajar juga dari pengalaman negara lain, keberadaan kamar kedua juga dalam rangka memberikan perspektif berbeda dari sisi pengalaman dan keahlian "the experience and expertise of members". ${ }^{40}$ Dengan gagasan tersebut, memungkinkan anggota partai politik yang senior untuk dapat menjadi anggota DPD dan memberdayakan pengalamannya, bukan sekedar mengisi jabatan semata seperti yang terjadi pada saat ini. Namun demikian, perlu diperhatikan kritik keberadaan kamar kedua, yakni adanya pengulangan 'redundency' termasuk kemungkinan deadlock sebagai akibat

\footnotetext{
${ }^{36}$ Meg Russell, The Contemporary House of Lords: Westminster Bicameralism Revived, Oxford University Press, Oxford, 2013, hlm. 67-78.

37 Wilson, Dilulio Jr., dan Bose, American Government: Institutions \& Policies, Op.Cit., hlm. 312. Lihat juga Manning, Membership of the 116 th Congress: A Profile, Op. Cit., hlm. 2-4.

${ }_{38} \mathrm{Meg}$ Russell, The Contemporary House of Lords: Westminster Bicameralism Revived, Oxford University Press, Oxford, 2013, hlm. 42.

${ }^{39}$ Philip Norton menyebut kamar kedua berperan untuk memperkuat perwakilian sekaligus refleksi kamar pertama dan pemerintahan. Philip Norton, "Adding Value? The Role of Second Chambers," Asia Pacific Law Review 15, No. 1, 2007, hlm. 6-8.

$40 \mathrm{Ibid}, 13$.
} 
kewenangan yang sama-sama berimbang antar kamar. ${ }^{41}$ Selain itu, perlu dicatat juga tulisan ini tidak dimaksudkan agar DPD dapat dikoopotasi oleh partai politik. Harus tetap dibuka kesempatan perorangan/independen untuk mencalonkan diri. Dengan demikian, anggota DPD dapat lebih bervariasi dengan tetap menonjolkan sisi keterlibatan daerah dalam kebijakan-kebijakan nasional.

\section{Penutup}

Berdasarkan uraian yang telah disampaikan, maka dapat disimpulkan, pertama, secara historis pembentukan DPD memang didesain untuk diisi oleh perorangan bukan dari partai politik. Praktik beberapa negara menunjukkan badan perwakilan "kedaerahan" secara alamiah umumnya tidak dapat dilepaskan dari partai politik. Oleh karena itu, dalam law in context, memisahkan DPD dengan partai politik secara "ketat" dapat dikatakan akan selalu dilanggar karena tidak sesuai dengan kondisi alamiah pengisian DPD secara langsung oleh rakyat, yang hampir dipastikan dipengaruhi oleh kekuatan jaringan dan dukungan partai politik dalam pemilihan umum. Hal ini dapat dilihat dari hasil pemilihan umum DPD tahun 2019, walau telah dinyatakan mundur dari partai politik, masih banyak anggota DPD terpilih, sebelumnya adalah anggota partai politik, yang tidak dapat diketahui secara pasti apakah yang bersangkutan masih terikat atau tidak dengan partai politik tersebut.

Kedua, prospek hubungan partai politik dengan DPD tidak akan memberikan dampak signifikan bagi optimalisasi peran DPD karena ketiadaan kewenangan yang memadai sebagai badan legislatif yang sebenarnya. Demikian juga keanggotaan DPD non-partai politik. Dengan demikian, ada-tidaknya anggota partai politik di DPD, tidak akan berpengaruh banyak pada penguatan aspirasi kedaerahan karena keterbatasan kewenangan DPD. Hubungan partai politik dengan DPD akan memiliki dampak yang signifikan jika DPD memiliki kewenangan signifikan sesuai tugas dan fungsi badan perwakilan.

Perlu peninjauan kembali DPD secara menyeluruh (integral) baik secara konstitusional maupun peraturan perundang-undangan di luar UUD 1945,

${ }^{41}$ Harus dilakukan penelitian tersendiri soal redundency dan deadlock dalam badan perwakilan. Lihat John Uhr, "Bicameralism," in The Oxford Handbook of Political Institution, ed. R. A. W. Rhodes, Sarah A. Binder, dan Bert A. Rockman, Oxford University Press, Oxford, 2006, hlm. 476-494. 
seperti kedudukannya sebagai badan perwakilan serta ketegasan hubungan (anggota) DPD dan partai politik. Jangan sampai berlaku ungkapan "ada tetapi tidak menggenapkan, tiada tidak pula mengganjilkan".

\section{Daftar Pustaka}

\section{Buku}

Australian Government Solicitor, Australia's Constitution With Overview and Notes by the Ausralian Government Solicitor, Barton, 2010.

Bahar, Saafroedin, A.B. Kusuma, dan Nannie Hudawati, ed., Risalah Sidang Badan Penyelidik Usaha-Usaha Persiapan Kemerdekaan Indonesia (BPUPKI), Panitia Persiapan Kemerdekaan Indonesia (PPKI), Sekretariat Negara RI, Jakarta, 1995.

Baker, Richard A. "The Senate of the United States." dalam Second Chambers, diedit oleh R.C. Tripathi, 256-272. Rajya Sabha Secretariat, New Delhi, 2002.

Banakar, Reza. Normativity in Legal Sociology: Methodological Reflection in Late Modernity, Normativity in Legal Sociology, Springer, Cham, 2015.

Finer, Herman, The Major Governments of Modern Europe, Methuen, London, 1960.

Harris, Bede, A New Constitution for Australia, Cavendish Publishing Limited, London, 2002.

Irianto, Sulistyowati, "Memperkenalkan Kajian Sosio-Legal dan Implikasi Metodologisnya", dalam Adrian Bedner, dkk. (ed), Kajian Sosio-Legal, Pustaka Larasan, Bali, 2012.

Manan, Bagir, DPR, DPD dan MPR dalam UUD 1945 Baru, FH UII Press, Yogyakarta, 2003.

Moens, Gabriel, John Trone, dan R.D. Lumb, The Constitution of the Commonwealth of Australia Annotated. Edisi 9, LexisNexis Butterworths, Chatswood DC, 2016.

Risse, Horst, "The Bundesrat in the Legislative Process of Federal Republic of Germany" dalam Second Chambers: Bicameralism Today, diedit oleh R.C. Tripathi, 105-110, Rajya Sabha Secretariat, New Delhi, 2002.

Russell, Meg, The Contemporary House of Lords: Westminster Bicameralism Revived, Oxford University Press, Oxford, 2013.

Sharma, S.R., ed., Encyclopaedia of Constitutional Law No. 5, Anmol Publications Pvt Ltd, New Delhi, 2003.

Tim Penyusun Naskah Komprehensif. Naskah Komprehensif Perubahan UndangUndang Dasr Negara Republik Indonesia Tahun 1945: Latar Belakang, Proses, dan Hasil Pembahasan 1999-2002. Buku III, Sekretariat Jenderal dan Kepaniteraan Mahkamah Konstitusi, Jakarta, 2010. 
Uhr, John, "Bicameralism", dalam The Oxford Handbook of Political Institution, diedit oleh R. A. W. Rhodes, Sarah A. Binder, dan Bert A. Rockman, 476494, Oxford University Press, Oxford, 2006.

Uslaner, Eric M., dan Thomas Zittal, "Comparative Legislative Behaviour", dalam The Oxford Handbook of Political Institution, diedit oleh R. A. W. Rhodes, Sarah A. Binder, dan Bert A. Rockman, 455-473. New York: Oxford University Press, 2006.

Wilson, James Q., John J. Dilulio Jr., dan Meena Bose. American Government: Institutions $\mathcal{E}$ Policies, Cengage Learning, Stamford, 2015.

\section{Jurnal dan Makalah}

Bagir Manan, "Penelitian Terapan Di Bidang Hukum", Makalah pada Lokakarya Peranan Naskah Akademik Dalam Penyusunan Peraturan PerundangUndangan, BPHN, Jakarta, 9-11 Desember 1993.

Enny Nurbaningsih, "Implikasi Putusan Mahkamah Konstitusi Nomor 92/PUUX/2012 dan Alternatif Model Hubungan Kelembagaan Terkait Pembentukan Undang-Undang" Mimbar Hukum, Vol. 27, No. 1, 2015.

Firman Manan, "Dewan Perwakilan Daerah Republik Indonesia Dalam Sistem Pemerintahan Republik Indonesia." Jurnal Ilmu Pemerintahan, Vol. 1, No. $1,2015$.

Jennifer E. Manning, Membership of the 116 th Congress: A Profile. Congressional Research Service, https://www.senate.gov/reference/resources/pdf/ R41647.pdf, diakses 20 April 2020.

Meg Russell, “The Territorial Role of Second Chambers." The Journal of Legislatives Studies, Vol. 7, No. 1, 2001.

Pan Mohamad Faiz dan Muhammad Reza Winata, "Respons Konstitusional Larangan Calon Anggota Dewan Perwakilan Daerah sebagai Pengurus Partai Politik." Jurnal Konstitusi Vol. 16, No. 3, 2019.

Philip Norton, "Adding Value? The Role of Second Chambers." Asia Pacific Law Review, lVol. 15, No. 1, 2007.

Putu Wawan Suryawan, dan I Ketut Rai Setiabudhi. "Sah Tidaknya Anggota Dewan Perwakilan Daerah Masuk Partai Politik." Kertha Negara 6, No. 3, 2018.

\section{Internet}

“Anggota DPD”, https://dpd.go.id/Fanggota/Anggota/34, diakses 20 April 2020.

"Anggota Forbes Haru dan Apresiasi Pemerintah Aceh", http:/ / humas.acehprov.go.id/anggota-forbes-haru-dan-apresiasipemerintah-aceh/, diakses 20 Desember 2020.

"Dianggap Galau, Anggota DPD Ramai-Ramai Ke Parpol" https://www.tribunnews.com/ nasional/2017/02/04/dianggap-galauanggota-dpd-ramai-ramai-ke-parpol, diakses 20 April 2020. 
"Jumlah Afiliasi Anggota DPD Dalam Partai Politik", Indonesian Parliamentary Center, http://ipc.or.id/wp-content/uploads/2017/04/garis.jpg, diakses 20 April 2020.

"Ketua MPR Inisiasi Forum Aspirasi Papua-Papua Barat", https://news.detik.com/berita/d-4806671/ketua-mpr-inisiasi-forumaspirasi-papua-papua-barat, diakses 20 Desember 2020.

"Oesman Sapta Odang Terpilih Jadi Ketua DPD." https://nasional.kompas.com/read/2017 /04/04/02314801/oesman. sapta.odang.terpilih.jadi.ketua.dpd, diakses 20 April 2020.

“Oesman Sapta Terpilih Menjadi Ketua DPD Gantikan Mohammad Saleh." https://news.detik.com/berita/d-3464194/oesman-sapta-terpilihmenjadi-ketua-dpd-gantikan-mohammad-saleh, diakses 20 April 2020.

"Pimpinan DPD Ginandjar Kartasamita", https://dpd.go.id/pimpinandpd/ginandjar-kartasasmita-, diakses 29 Maret 2021.

Sorik, Sutan, "Pengurus Parpol Dilarang Jadi Anggota DPD: Kepentingan Politik Praktis atau Amanah Konstitusi?" Pusat Penelitian Politik LIPI. http:/ /www.politik.lipi.go.id/kolom/kolom-2/politik-nasional/1249pengurus-parpoldila rang-jadi-anggota-dpd-kepentingan-politik-praktisatau-amanah-konstitusi\#ftn5, diakses 20 April 2020.

"Taufiq Kiemas Pimpin MPR", https://koran.tempo.co/read/nasional/ 178000/taufiq-kiemas-pimpin-mpr, diakses 29 Maret 2021.

\section{Peraturan Perundang-Undangan dan Putusan Pengadilan}

Undang-Undang Dasar Negara Repulik Indonesia Tahun 1945.

Penetapan Presiden Nomor 2 Tahun 1959 tentang Majelis Permusyawaratan Rakyat Sementara, Lembaran Negara Republik Indonesia Tahun 1959 Nomor 77, Tambahan Lembaran Negara Republik Indonesia Nomor 1816.

Peraturan Presiden Nomor 12 Tahun 1959 tentang Susunan Majelis Permusyawaratan Rakyat Sementara, Lembaran Negara Republik Indonesia Tahun 1959 Nomor 150, Tambahan Lembaran Negara Republik Indonesia Nomor 1917.

Penetapan Presiden Nomor 4 Tahun 1960 tentang Dewan Perwakilan Rakyat Gotong Royong, Lembaran Negara Republik Indonesia Tahun 1960 Nomor 78, Tambahan Lembaran Negara Republik Indonesia Nomor 2015.

Putusan Mahkamah Konstitusi Nomor 30/PUU-XVI/2018.

Putusan Mahkamah Konstitusi Nomor 92/PUU-X/2012.

Putusan Mahkamah Agung Nomor 65P/HUN/2018. 